\title{
Subcellular Localization of Diacylglycerol-responsive Protein Kinase C Isoforms in HeLa Cells
}

\author{
Julhash U. Kazi, Cho-Rong Kim, and Jae-Won Soh* \\ Biomedical Research Center for Signal Transduction Networks, Department of Chemistry, Inha Chiversity \\ Incheon $402-751$, Korea. "E-mail: sohia inhack \\ Received Jine 8, 2009, Accepted July 13, 2009
}

\begin{abstract}
Subcellular localization of protein kinase often plays an important role in determining its activity and specificity. Protein kinase $\mathrm{C}(\mathrm{PKC}$ ), a family of multi-gene protein kinases has long been known to be translocated to the particular cellular compartments in response to DAG or its analog phorbol esters. We used C-terminal green fluorescent protein (GFP) fusion proteins of $\mathrm{PKC}$ isofonns to visualize the subcellular distribution of individual $\mathrm{PKC}$ isoforms. Intracellular localization of PKC-GFP proteins was monitored by fluorescence microscopy after transient transfection of PKC-GFP expression vectors in the HeLa cells. In unstimulated HeLa cells, all PKC isoforms were found to be distributed throughout the cytoplasm with a few exceptions. PKC $\theta$ was mostly localized to the Golgi, and PKC $\gamma$, $\mathrm{PKC} \delta$ and $\mathrm{PKC} \eta$ showed cy toplasmic distribution with Golgi localization. DAG analog TPA induced translocation of PKC-GFP to the plasma membrane. PKC 2 . PKC n and PKC $\theta$ were also localized to the Golgi in response to TPA. Orly PKCo was found to be associated with the nuclear membrane after transient TPA treatment. These results suggest that specific $\mathrm{PKC}$ isoforms are translocated to different intracellular sites and exhibit distinct biological effects.
\end{abstract}

Key Worts: PKC. TPA. HeLa. Translocation. Localization

\section{Introduction}

Protein kinase $\mathrm{C}(\mathrm{PKC})$ is a multi-gene family of at least 10 protein serine/threonine kinases. ${ }^{1 . \hat{P}} \mathrm{PKC}$ isoforms regulate diverse cellular signaling pathways by phosphorylating their downstream kinases and substrate proteins. Activation of $\mathrm{PKC}$ isoforms results in cellular transformation. proliferation. differentiation and tumorigenesis. Certain PKC isoforms are also reported to be involved in growth inhibition and apoptosis. ${ }^{3}$ These effects might be regulated by their subcellular localization and stimulus-induced translocation. ${ }^{4.5}$

PKC isoforms consist of an amino-terminal regulatory domain and a carboxy -teminal cataly tic domain. Based on the structural similarity and cofactor requirement. $\mathrm{PKC}$ isoforms can be subdivided into three groups. Classical PKC isoforms ( $\alpha \beta 3$ l. $\beta 2, \gamma)$ contain two $C 1$ domains and a $C 2$ domain which are regulated by diacylglycerol (DAG) and $\mathrm{Ca}^{{ }^{-}}$. Novel PKC isoforms $(\delta . \varepsilon, \eta, \theta)$ are regulated by DAG. but not by $\mathrm{Ca}^{2-}$. These isoforms contain a novel $\mathrm{C} 2$ domain that lacks conserved $\mathrm{Ca}^{2+}$ binding residues. Atypical $\mathrm{PKC}$ isoforms $(\zeta, 1)$ are not responsive to either DAG or $\mathrm{Ca}^{2-}$. These two isoforms lack $\mathrm{Clb}$ and $\mathrm{C} 2$ domains.

Binding of DAG to the $\mathrm{Cl}$ domains plays an important role in the subcellular localization and activation of classical and novel $\mathrm{PKC}$ isoforms. $\mathrm{PKC}$ interacting proteins are also thought to be involved in these processes. ${ }^{4} \mathrm{DAG}$ analog phorbol esters. such as 12-O-tetradecanoylphorbol-13-acetate (TPA), can bind to the $\mathrm{CI}$ domains activating classical and novel PKC isoforms. We and several investigators studied the subcellular localization and TPA-induced translocation of $\mathrm{PKC}$ isoforms in different cell lines. ${ }^{6-8}$ The localization patterns of different $\mathrm{PKC}$ isoforms might be isoform and cell line specific. For example, PKC $\alpha$ was found to be localized to the cytoplasm and TPA induced translocation to the plasma membrane in NIH3T3 cells. whereas
PKC $\alpha$ was reported to be translocated from the cytoplasm to the plasma membrane and the nucleus in rat liver WB cells. ${ }^{6.8}$ PKCô was shown to be localized to the cytoplasm and the mucleus in unstimulated $\mathrm{CHO}-\mathrm{KI}$ cells and TPA induced translocation to the plasma membrane and the nuclear membrane." However, we did not observe any nuclear accunulation of PKCô in NIH3T3 cells. Other $\mathrm{Cl}$ domain targeting stimuli such as bryostatin 1 also induced translocation of $\mathrm{PKC}$ isoforms from the cytoplasm to the plasma membrane.

While PKC isoforms have distinct roles in various cancers, the localization patterns of $\mathrm{PKC}$ isoforms in cancer cells have not been studied well. Recently the subcellular localization and TPA-induced translocation of $\mathrm{PKCn}$ were studied in breast cancer cells. ${ }^{11}$ Ceramide-mediated translocation of several PKC isoforms was also investigated in human myelogenous leukemia HL- 60 cells. ${ }^{12}$ In this study. we studied the subcellular localization of DAG-dependent PKC isofornts in HeLa cervical cancer cells. We used green fluorescent protein (GFP)-fused $\mathrm{PKC}$ isoforms to visualize the localization patterns in living cells.

\section{Experimental Section}

Plasmids. pGFP3-PKC $\alpha$-WT, pGFP3-PKC $\beta 1-W T$, pGFP3PKCB2-WT. pGFP3-PKC $\gamma$-WT, pGFP3-PKCô-WT. pGFP3PKC $\varepsilon-W T$ and pGFP3-PKCn-WT plasmids were described previously. ${ }^{6}$ pGFP3-PKC $\theta$-WT plasmid was constructed by subcloning the BamHI fragment of full length open reading frame of $\mathrm{PKC} \theta$ isoform into the pGFP3 ${ }^{6}$ expression vector.

Cell Transfection. HeLa cells were grown in DMEM containing $10 \%$ calf senum Triplicate of $1 \times 10^{5}$ cells in $35 \mathrm{~mm}$ plates were transfected by lipofectin (Gibco BRL) with $5 \mu$ g of expression plasmid. pGFP3 was used as empty control vector.

Westem Blotting. Six hours after transfection. cells were 


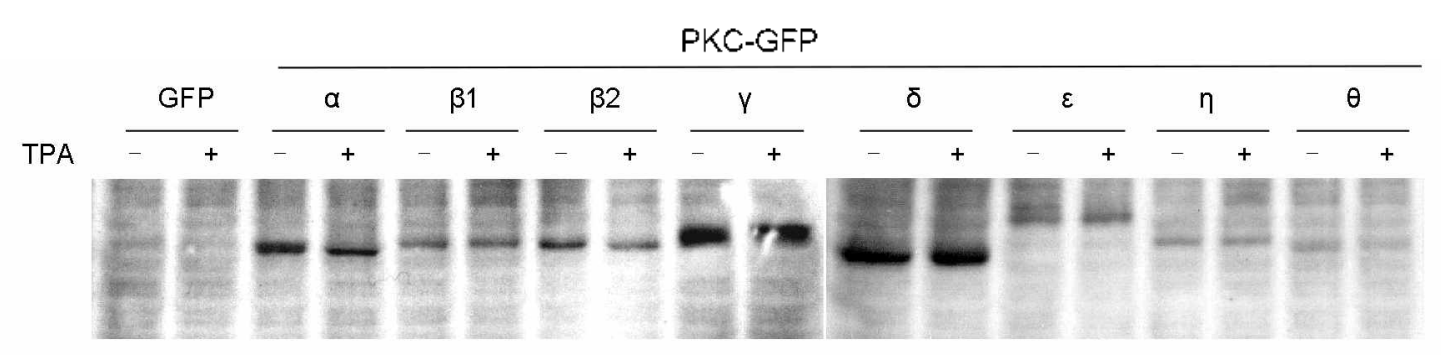

Western blotting: anti-GFP antibody

Figure 1. Overexpression of GFP tusion PKC isotorms. HeLa cells were transtected with pGFP3-PKC-WT plasmids or empty control vector. After transient expression cells were treated with $100 \mathrm{ng} / \mathrm{mL}$ of TPA for 10 minutes or DMSO and cellular proteins were extracted by cell lysis. Westem blotting was pertorned using an anti-GFP antibody.
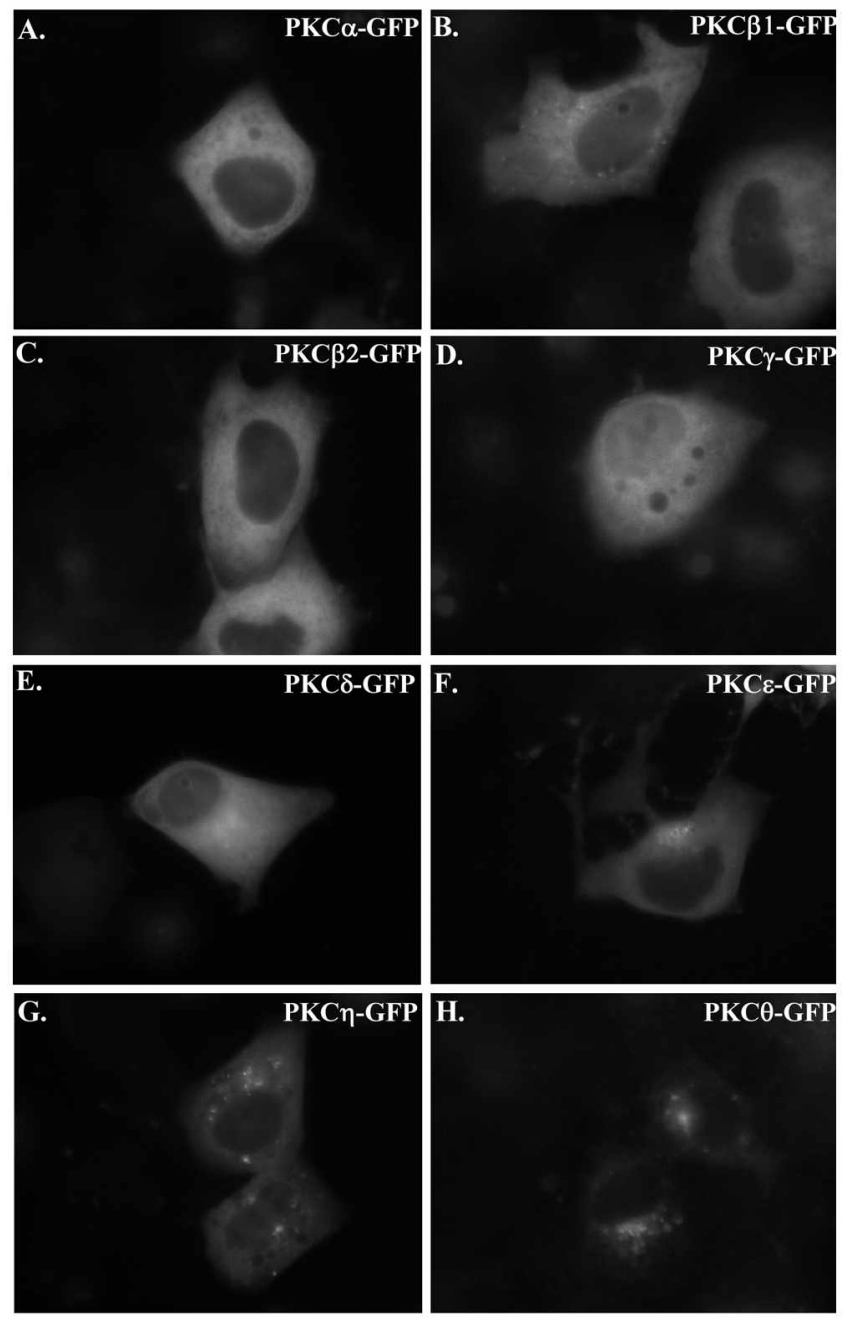

Figure 2. Subcellular localization of PKC isofonms. HeLa cells were transtected with pGFP3-PKC-WT plasmids. After 24 hours of transfection in senum free medium nucleus was stained with Hoechst 33258 for 30 minutes. Fluorescent images of HeLa cells espressing PKCGFP were taken using a tluorescence microscope.

fed with DMEM containing 10\% calf serum and left to stand overnight. The cells were then transferred to $10 \mathrm{~cm}$ plates and grown for 24 hours before protein extraction. The cellular proteins were extracted by cell lysis in RIPA buffer $(50 \mathrm{mM}$ Tris HCl. pH 8.0. $150 \mathrm{mM} \mathrm{NaCl}, 1 \% \mathrm{NP}-40,0.1 \%$ sodium dodecyl sulfate, $0.5 \%$ deosycholate, $2 \mathrm{mM}$ EDTA, $2 \mathrm{mM}$ EGTA. $1 \mathrm{mM}$ dithiothreitol) containing protease inhibitors ( $10 \mu \mathrm{g} / \mathrm{mL}$ aprotinin. $10 \mu \mathrm{g} / \mathrm{mL}$ leupeptin, $0.1 \mathrm{mM}$ PMSF) and plosphatase inhibitors ( $1 \mathrm{mMNaF}, 0.1 \mathrm{mMNa} \mathrm{VO}_{4}, 10 \mathrm{mM} \beta$-glycerophosphate). The GFP-fusion proteins were immunoprecipitated from $300 \mu \mathrm{g}$ of the cell extracts using $3 \mu \mathrm{g}$ of anti-GFP antibody and $30 \mu \mathrm{L}$ of protein G-Sepharose. after 3 hours of incubation at $4{ }^{\circ} \mathrm{C}$ and analyzed by SDS-PAGE and Westem blotting system.

Fluorescence Microscopy. Twenty-four hours after transfection in serun-free mediun, Hoechst 33258 was added to the medium at a concentration of $1 \mu \mathrm{g} / \mathrm{mL}$ to stain nuclei for 30 minutes. The plates were then placed under the fluorescent microscope. TPA was added to the medium at a concentration of $100 \mathrm{ng} / \mathrm{mL}$ to stimulate PKC translocation. Before and after 10 mimutes of TPA treatment. fluorescent images from both green (GFP) and blue (nuclei) were recorded. Fluorescence images were taken using $488 \mathrm{~nm}$ as excitation wavelength and $509 \mathrm{~nm}$ as enission wavelength.

\section{Results}

To explore the expression patterns of PKC-GFP and the stability of intact proteins upon TPA treatment. we transfected HeLa cells with pGFP3-PKC-WT constructs or empty control vector. After transient expression. the expression levels of the overexpressed PKC-GFP proteins were examined by Westem blotting using anti-GFP antibody, without TPA stimulation and after 10 minutes of TPA stimulation. No significant difference of PKC-GFP protein levels was observed between the stimulated and unstimulated cells (Fig. 1). which suggests that PKC-GFP proteins were expressed as intact protein in unstinulated cells and transient TPA treatment did not alter that protein levels.

pGFP3-PKC-WT constructs were transfected into the HeLa cells to investigate the subcellular localization of $\mathrm{PKC}$ isofonms in cervical cancer cells. The subcellular localization of PKCGFP was observed with florescence microscopy after transient expression. Classical PKC isofonns showed homogeneous distribution throughout the cytoplasm (Fig. 2A, 2B, 2C and 2D). suggesting that classical $\mathrm{PKC}$ isoforms were present in abundant amounts in the cytoplasm of the unstimulated cells and that these isoforns were inactive in absence of agonist. PKC $\gamma$ was found to be localized to the Golgi with a cytoplasmic distribution (Fig. 2D) while PKC $\beta 1$ showed granular distribution (Fig. 2B). Novel $P K C$ isoforms showed differential localization patterns within this subfamily. For example. PKCồ was distributed th- 

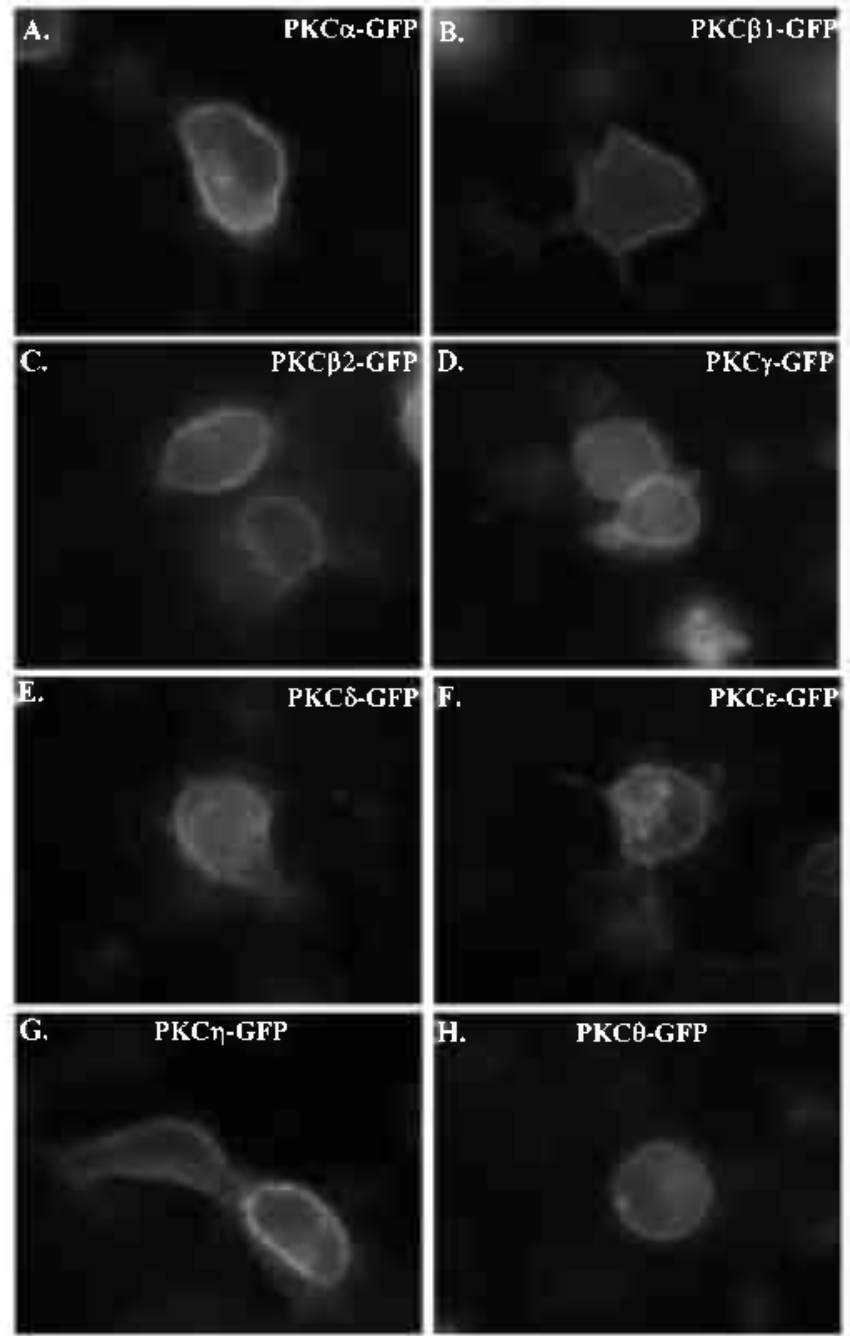

Figure 3. TPA induced translocation of PKC isofonms. HeLa cells were transfected with pGFP3-PKC-WT plasninds. After 24 hours of transfection in senum free medium, nucleus was stained with Hoechst 33258 tor 30 minutes. Fluorescent inages of HeLa cells expressing PKC-GFP were taken after 10 minutes of TPA stimulation.

roughout the cy toplasm and also was localized to the perimuclear regions such as Golgi in the unstimulated cells (Fig. 2E). PKCE was distributed throughout the cy'toplasm with trans-Golgi localization (Fig. 2F). PKC ) was present mainly in the Golgi with a granular cy toplasmic distribution (Fig. $2 \mathrm{G}$ ) and $\mathrm{PKC} \theta$ was present mostly in the Golgi and the endoplasmic reticulum (Fig. 2H).

After 10 minutes of treatment with $100 \mathrm{ng} / \mathrm{mL}$ TPA. all classical and novel $\mathrm{PKC}$ isoforms were translocated to the plasma membrane with a few exceptions (Fig. 3). PKCa (Fig 3A). $\mathrm{PKC} \varepsilon$ (Fig. 3F) $\mathrm{PKCn}$ (Fig. 3G) and $\mathrm{PKC \theta}$ (Fig. 3H) were also present in the Golgi after TPA treatment. PKC $\delta$ was translocated to both plasma membrane and nuclear membrane with Golgi localization (Fig. 2E). PKC 1 1 (Fig. 3B). PKCß2 (Fig. 3C) and $\mathrm{PKC}_{\gamma}$ (Fig. 3D) were found to be translocated mainly to the plasma membrane. These results suggest that majority of activated $\mathrm{PKC}$ isoforms are localized to the plasma membrane and specific PKC isoforms exhibit their specific localization patterns.

\section{Discussion}

PKC isofonms play central roles in several signal transduction pathways which regulate cell proliferation differentiation and apoptosis. Several PKC isoforms are expressed abundantly in various cancer cells including cervical cancer cells. ${ }^{[?]+}$ A number of factors. such as cell type. stimuli and specific isoforms have the distinct functions in PKC-nediated signal transduction pathways. ${ }^{15.16}$ Subcellular localization of PKC isoforms and their substrate specificity may contribute to this diversity. Localization of $\mathrm{PKC}$ isofonms might be mediated by the isofonm specific cofactors and the interacting proteins. Several investigators have described the subcellular localization of PKC isoforms using various methods. ${ }^{6 \% 11.1 \% 18}$ In this study, we investigated the differential localization of PKC isoforms in the form of GFP fusion protein in HeLa cells. Results presented here suggest that inactive PKC isoforms are nostly localized to the cytoplasm and DAG-responsive PKC isoforms are generally translocated to the plasma membrane upon TPA stimulation.

$P K C \alpha . P K C \beta 1$ and $P K C \beta 2$ were well distributed throughout the cytoplasm in unstimulated cells. indicating that these isoforms are inactive in unstinulated HeLa cells. A portion of $\mathrm{PKC} \gamma . \mathrm{PKC} \hat{\mathrm{o}} . \mathrm{PKC} \varepsilon$ and $\mathrm{PKC} \theta$ isofonns might be activated in unstimulated cells as they were found to be localized to the cytoplasmic cell organelles such as Golgi and endoplasmic reticulum. Golgi localization of $\mathrm{PKC} \gamma$ and $\mathrm{PKCò} \mathrm{was} \mathrm{also}$ observed in NIH3T3 cells. However. PKC $\varepsilon$ was found to be distributed throughout the cytoplasm in $\mathrm{NIH} 3 \mathrm{~T} 3$ cells. it was localized to the Golgi in HeLa cells. This finding may suggest that $\mathrm{PKC} \varepsilon$ plays a role in unstinulated HeLa cells. $\mathrm{PKC} \varepsilon$ is known to have oncogenic potential. The nuclear localization of PKCo was reported in CHO-Kl cells. ${ }^{9}$ However. we did not observe any nuclear accumulation of this novel PKC isoform either in HeLa cells or in NIH3T3 cells. ${ }^{6}$ Recently it was reported that $\mathrm{PKC} \delta$ contains a carboxy -terminal bipartite nuclear localization signal and was localized to the nucleus in response to the apoptotic signals inducing apoptosis. ${ }^{19,201}$ However. it is still unclear that how PKCó is localized to the nucleus in certain unstinulated cells.

$\mathrm{PKC}$ inhibitors such as $\mathrm{UCN}-0 \mathrm{I}$ induce growth inhibition in cervical cancer cells ${ }^{2]}$ by inluibiting endogenous $\mathrm{PKC}$ isoforms. $\mathrm{PKC}$ isoforms are translocated to the plasma membrane and activate several substrate proteins. resulting in cell proliferation. PKC binding proteins such as RACK might be involved in this process. Localization of activated PKC $\alpha$ to cytoplasmic membranous organelles, ${ }^{6,18.22}$ nuclear membrane ${ }^{23}$ and nucleus ${ }^{24}$ was observed in different cell lines. In HeLa cells, we observed that PKC $\alpha$ was translocated to the plasma membrane and to the Golgi. $\mathrm{PKC} \varepsilon$ and $\mathrm{PKC} \theta$ also showed same translocation pattems. Only PKCô was translocated to the nuclear membrane with plasma membrane and Golgi co-localization. These observations suggest that subcellular localization $\mathrm{PKC}$ isoforms is specific to the PKC isoforms as well as to the cell types.

Acknowledgments. This work was supported by INHA UNIVERSITY Research Grant. 


\section{References}

1. Newton, A. C. Biochem. J. 2003, 370, 361 .

2. Kazi, J. U.; Kabir, N. N.; Soh, J. W. Gene 2008, 410, 147.

3. Lee, Y. J.: Soh, T. W.: Teoung, D. I.; Cho, C. K.: Jhon, G. I.; Lee, S. T. Lee, Y. S. Biochim. Biophs. Acta 2003, 1593, 219.

4. Spitaler, M.; Cantrell, D. A. Kat. Immunol. 2004, 5,785

5. Shirai, Y.; Saito, N. J. Biochem. (Tohvo) 2002, 132, 663.

6. Kazi, T. U.: Soh. T. W. Biochem Biophis. Res. Commm 2007, 364, 231

7. Sakai, N.: Sasaki, K.; Ikegaki, N.; Shirai, Y.; Ono, Y.; Saito, N. J. Cell. Biol. 1997, 139, 1465

8. Maloney, J. A.; Tsygankova, O.: Szot, A.: Yang, L.; Li, Q.; Williamson, J. R. Ant. J. Phisiol 1998, 27t, C974.

9. Wang, Q. T.; Bhattacharya, D.; Garfield, S.; Nacro, K.; Marquez, V. E.; Blumberg, P. M. J. Biol Chem. 1999, 27ł, 37233

10. Hocevar, B. A.: Fields, A. P. J. Biol Chem. 1991, 266, 28.

11. Maissel, A.: Marom, M.: Shtutman, M.; Shahaf, G.; Livneh, E. Cell Sighat 2006, 18, 1127.

12. Sawai, H.; Okazaki, T.; Takeda, Y: Tashima, M.; Sawada, H.; Okuma, M.: Kishi, S.: Umehara, H.: Domae, N. J. Biol Chem.
$1997,272,2452$

13. Soh, I. W.: Lee, Y. S.: Weinstein, I. B. J. Exp. Ther Oncol. 2003, 3,115 .

14. Kạjimoto, T: Ohmori, S.; Shirai, Y.; Sakai, N.: Saito, N. M fol Cell. Biol. 2001, 21, 1769

15. Kazi, J. U.; Soh, J. W. Mol. Cells 2008, 26, 462.

16. Kazi, J. U.; Soh, J. W. Bull Korean Chem. Soc. 2008, 29,252

17. Xu, T. R.: Rumsby, M. G. FEBS Let 2004, 570, 20.

18. Goodnight, T. A.; Mischak, H.; Kolch, W.; Mushiriski, J. F. J. Biol. Chem. 1995, 270,9991.

19. DeVries, T. A.; Neville, M. C.; Reyland, M. E. Embo.J. 2002, 21, 6050 .

20. DeVries-Seimon, T. A.; Ohm, A. M.; Humphries, M. T.; Reyland, M. E. J. Biol. Chem. 2007, 282, 22307

21. Sommers, G. M; Alfieri, A. A. Cancer lnvest. 1998, 16, 462.

22. Almholt, K.; Arkhammar, P. O; Thastrup, O.; Tullin, S. Biochem. J. 1999, 337( Pt 2), 211.

23. Johnson, I. A.; Gray, M. O.: Chen, C. H.: Mochly-Rosen, D. J. Biol. Chem. 1996, 271, 24962.

24. Wagner, S.: Harteneck, C.; Hucho, F.: Buchner, K. Exp. Cell Res. 2000, 258,204 